\title{
A new species of bumblebee catfish of the genus Microglanis (Siluriformes: Pseudopimelodidae) from the upper rio Paraguay basin, Brazil
}

\author{
Oscar Akio Shibatta
}

A new species of Microglanis from upper rio Paraguay basin is described. The species differs from congeners by the following combination of characters: deeply forked caudal fin with pointed lobes, bifurcated hook between antrorse and retrorse hooks on anterior margin of pectoral-fin spine, lateral line relatively long, surpassing the vertical through end of dorsal fin but not reaching adipose fin, color pattern of dorsal region of head dark brown with a restrict thin light area between anterior nostril and eye, broad light stripe on supraoccipital region.

Uma nova espécie de Microglanis da bacia do alto rio Paraguai é descrita. A espécie difere das congêneres pela seguinte combinação de caracteres: nadadeira caudal profundamente furcada com lobos pontiagudos, serra bifurcada entre as serras antrorsas e retrorsas da margem anterior do espinho da nadadeira peitoral, linha lateral relativamente longa, ultrapassando a vertical que passa pelo final da base da nadadeira dorsal, mas não atingindo a nadadeira adiposa, padrão de colorido da região dorsal castanho escuro com uma estreita área clara restrita entre a narina anterior e o olho, faixa clara larga na região supraoccipital.

Keywords: Microglanis carlae, Microglanis cottoides, Multivariate morphometrics, Pantanal, Systematics.

\section{Introduction}

Microglanis Eigenmann, 1912 is a genus of Neotropical catfishes composed by small species (smaller than $80 \mathrm{~mm}$ SL), identified by the color pattern with large dark brown blotches, eye covered by skin, incomplete lateral line, and lateral of dentigerous plate not prolonged backward (Gomes, 1946; Mees, 1974). It is the most species-rich genus of Pseudopimelodidae, currently comprising 22 described species (Shibatta, 2014).

The geographic distribution of Microglanis is the widest among other genera of Pseudopimelodidae, occurring since the transandinean region of Ecuador, and in the main hydrographic basins of cisandinean region. For the upper rio Paraguay basin in Pantanal region, Britski et al. (2007) and Polaz et al. (2014) mentioned M. cottoides Boulenger, 1891, a species originally described to rio Camaquã, laguna dos Patos basin, a coastal system unconnected to Paraná-Paraguay basin. Another species assigned to rio Paraguay basin is M. carlae Alcaraz, Graça \& Shibatta, 2008, described from its lower region at Paraguay. Alcaraz et al. (2008) also examined a specimen from upper rio Paraguay basin (NUP 3533) and supposed it belonged to another species, probably new to science. A detailed morphological analysis of this and additional specimens highlight differences between specimens collected in upper rio Paraguay basin and $M$. cottoides of coastal region, as well as to $M$. carlae, allowing the description of a new species presented herein.

\section{Material and methods}

Morphometric variables of specimens were taken pointto-point with digital caliper with accuracy of $0.01 \mathrm{~mm}$, under a stereomicroscope. Both counts and measurements were taken on the left side of specimens whenever possible. Measurements were taken following Shibatta (2014), totaling 22 morphometric variables. Measurements were presented as percents of standard length (SL), except the subunits of head, presented as percents of head length (HL). Meristic data included counts of gill rakers, serrations of pectoral-fin spine, lateral line pores, and dorsal, pectoral, pelvic, anal and caudal-fin rays. Roman numerals indicate unbranched rays and Arabic numerals represent branched rays. In the diagnoses and descriptions of species, the frequency of each meristic data is presented in brackets and the counts of the holotypes are followed by asterisks. Specimens of $M$. carlae and M. cottoides were added to perform the sheared Principal Components Analysis (MacLeod, 1990). For this analysis, 20 variables 
were selected from original morphometric list (excluding head depth and body depth, due to limitations on number of morphometric variables accepted by the program). International Union for Conservation of Nature and Natural Resources (IUCN) Red List Categories (2012) was used to infer the conservation status of the new species.

Institutional abbreviations are: ANSP (Academy of Natural Sciences, Philadelphia); CAS (California Academy of Sciences, San Francisco); INPA (Instituto Nacional de Pesquisas da Amazônia, Manaus); MCN (Museu de Ciências Naturais, Fundação Zoobotânica, Porto Alegre); MCP (Museu de Ciências e Tecnologia da Pontifícia Universidade Católica do Rio Grande do Sul, Porto Alegre); MEPN (Museo de la Escuela Politécnica Nacional de Quito, Ecuador); MNHNP (Museu Nacional de Historia Natural del Paraguay, San Lorenzo); MNRJ (Museu Nacional, Rio de Janeiro); MZUEL (Museu de Zoologia da Universidade Estadual de Londrina, Paraná); MZUSP (Museu de Zoologia da Universidade de São Paulo, São Paulo); MHNG (Muséum D'Histoire Naturelle de Genève, Geneva); USNM (National Museum of Natural History, Smithsonian Institution,Washington); NUP (Coleção ictiológica do Núcleo de Pesquisas em Limnologia, Ictiologia e Aquicultura, Universidade Estadual de Maringá, Maringá), ROM (Royal Ontario Museum, Toronto), and ZUFMSPIS (Coleção de Peixes da Universidade Federal do Mato Grosso do Sul, Campo Grande).

\section{Results}

\section{Microglanis leniceae, new species}

urn:1sid:zoobank.org:act:2566F7BE-D279-4012-816D8C43ACF4C570

\section{Figs. 1 - 2}

Holotype. ZUFMS 4148, $33.0 \mathrm{~mm}$ SL, Brazil, Mato Grosso do Sul, Miranda, upper rio Paraguay basin, rio Betione, 20²5'25”S 56²3'57” W, 18 May 2013, H. Gimenes Jr.

Paratypes. Brazil, Mato Grosso do Sul: ZUFMS 4143, 1, $30.1 \mathrm{~mm}$ SL, same data as holotype. Mato Grosso: INPA 27582, 4, 19.5-21.0 mm SL, Araputanga, rio das Pitas, 1609'45"S 5800'05”W, 28 Ago 1984, V. Py-Daniel. NUP 3533, 1, 29.1 mm SL, Santo Antônio do Leverger, Barão de Melgaço, upper rio Paraguay basin, rio Cuiabá, $15^{\circ} 58^{\prime} \mathrm{S}$ $55^{\circ} 56^{\prime} \mathrm{W}, 20$ Jan 2003.

Diagnosis. Microglanis leniceae differs from all congeners, except M. lundbergi Jarduli \& Shibatta, 2013, by the deeply forked caudal fin with pointed lobes, a character invariable even in small specimens (vs. emarginated, rounded, or bifurcated with rounded lobes). Differs from M. lundbergi, by lateral line canal surpassing vertical through end of dorsal fin (vs. not surpassing), 8 to 11 pores on lateral line (vs. 6 to
8), larger dorsal-fin spine length (15.1-17.8\% vs. $11.4-15.9 \%$ SL), larger predorsal length $(38.0-39.5 \%$ vs. $35.5-38.6 \%$ SL), larger interobital width (44.1-51.2\% vs. 40.4-44.2\% HL), and larger mouth width (61.5-72.0\% vs. 38.0-47.3\% HL). Differs from M. cottoides, another species mentioned to the upper rio Paraguay basin, and M. carlae, the species from lower rio Paraguai basin, by the bifurcated hook on anterior margin of pectoral-fin spine ( $v s$. antrorse and retrorse only).

Description. Morphometric data are presented in Table 1. Body depressed from snout to dorsal-fin origin; posteriorly compressed. Dorsal profile slightly oblique upward from snout tip to posterior nostril; slightly convex from posterior nostril to nape; slightly oblique from nape to dorsal-fin origin. Profile from dorsal-fin origin to end of adipose-fin base almost straight (not considering adipose fin), oblique downward. Dorsal profile straighter on small specimens. Ventral profile from tip of lower jaw to end of anal-fin base slightly convex, almost straight. Head large, wider than deep. Mouth terminal, slightly prognathous. Opercular membrane large, well developed. Eye relatively small, covered by skin. Anterior nostril tubular, on superior lips. Posterior nostril rounded, membranous flap on posterior margin, near to eye than to anterior nostril. Maxillary and outer mental barbels slightly surpassing pectoral fin base.

Dorsal fin trapezoidal; posterior border rounded; origin anterior to standard length midpoint; not reaching adiposefin origin when adpressed; first lepidotrichium ("spinelet") small and rigid, forming dorsal-fin locking mechanism; second ray forming spine, smooth on anterior and posterior margin; I, 6*(6). Adipose fin slightly elongated, posterior border angular and free. Pectoral fin triangular, not reaching pelvic-fin origin when adpressed; first ray rigid, pointed, flattened, slightly arched, strongly serrated on both sides, bifurcated hook between antrorses (distal) and retrorses (proximal) hooks on anterior margin; retrorses hooks on posterior margin (Fig. 2); I, $5^{*}(6)$. Specimens larger than $21.0 \mathrm{~mm}$ SL: retrorses hooks on anterior margin $8^{*}(2)$ to $9(1)$; bifurcated hook $0(1)$ to $1^{*}(2)$; antrorses hooks $3^{*}(2)$ or $7(1)$; small hooks, straight, near tip $0(1), 1(1), 2^{*}(1)$; retrorses hooks on posterior margin $7 *(1)$ or $10(2)$. Specimens smaller than $21.0 \mathrm{~mm}$ SL: retrorses hooks, proximal 9(2); smaller and straight hooks, distal 2(2) on anterior margin; retrorses hooks on posterior margin 6(1) or 7(1). Pelvic fin rounded, originating just posterior to vertical through end of dorsalfin base, not reaching anal-fin origin when adpressed; i, $5^{*}(6)$. Anal fin distal profile rounded; anal-fin base length slightly smaller than adipose-fin base; iii, $6^{*}(5) /$ iv, 5(1). Caudal fin deeply forked; lobes distal profiles pointed; usually lower lobe slightly longer than upper lobe (opposite in one paratype); principal rays i, 7, 6, i (1)* or i, 6, 7, i (5).

Lateral line incomplete, pores extending just beyond vertical through posterior margin of pelvic-fin, at middle distance between dorsal fin to adipose fin; lateral line pores $8(4), 9(1)$, or $11^{*}(1)$. Total gill rakers 5(2), 6(1), 7(2), or 9*(1). Axillary pore absent. 

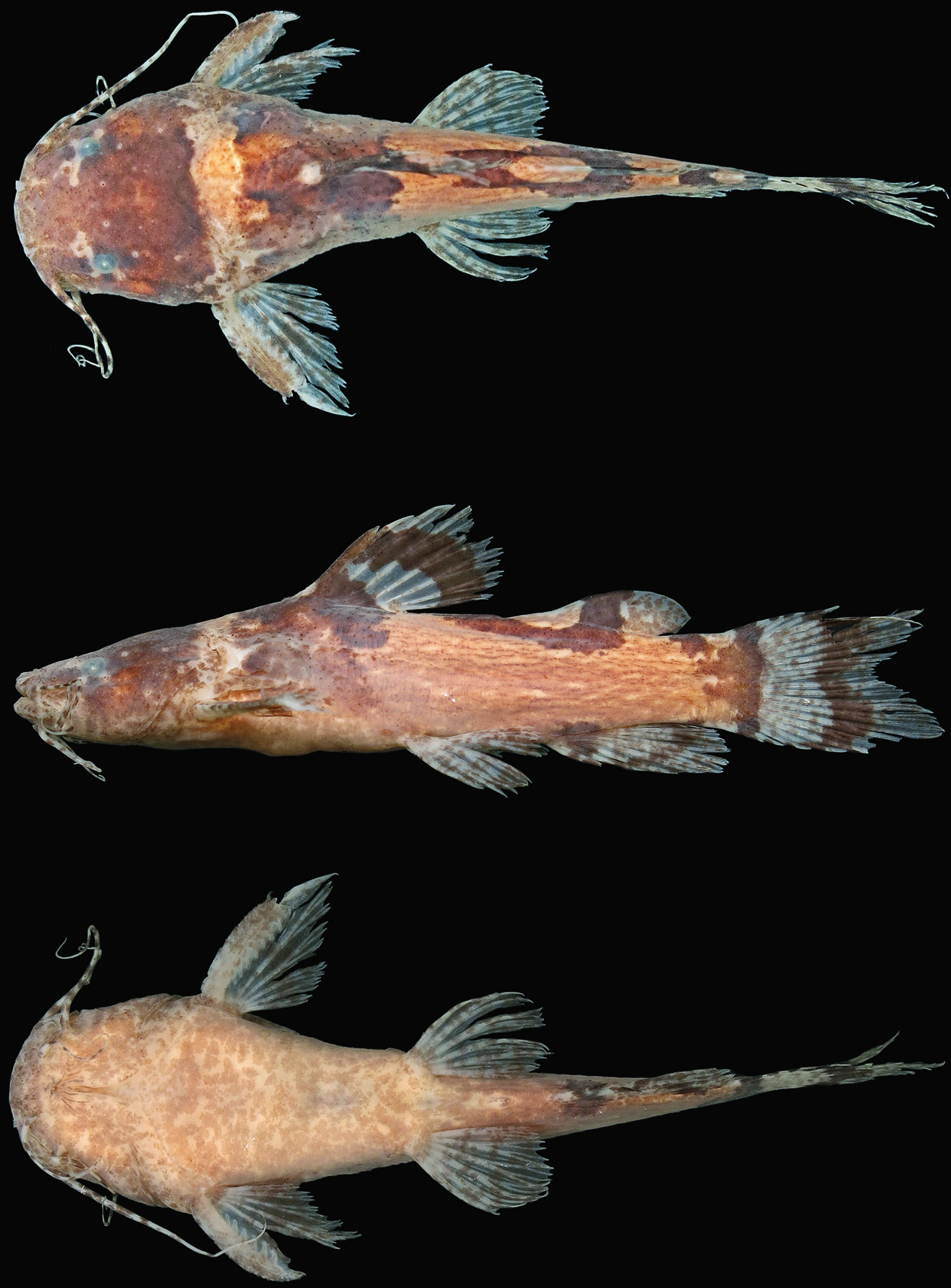


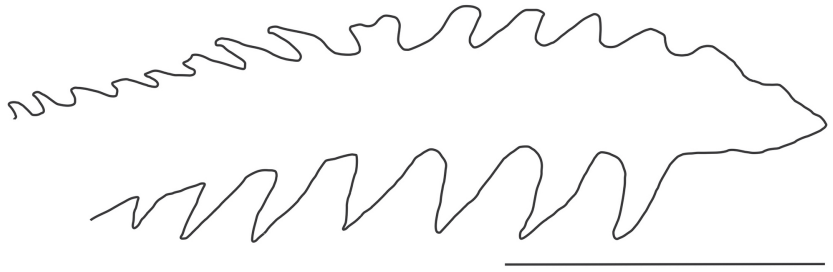

Fig. 2. Dorsal view of right pectoral-fin spine of holotype (ZUFMS 4148, $33.0 \mathrm{~mm} \mathrm{SL}$ ) of Microglanis leniceae, from the upper rio Paraguay basin, Mato Grosso State, Brazil. Scale bar $=1 \mathrm{~mm}$.

Table 1. Morphometrics of Microglanis leniceae from the upper rio Paraguay $(n=6)$. Minimum and maximum (MinMax) include the data of holotype. $\mathrm{SD}=$ Standard deviation.

\begin{tabular}{lccc}
\hline & Holotype & Min-Max & Mean \pm SD \\
\hline Standard length & 33.0 & $19.5-33.0$ & $25.4 \pm 6.0$ \\
& Proportion of standard length & \\
Head length & 28.4 & $26.5-29.3$ & $28.0 \pm 1.0$ \\
Pelvic fin length & 17.7 & $17.7-20.0$ & $19.1 \pm 1.0$ \\
Dorsal-fin spine length & 15.2 & $15.1-17.8$ & $16.1 \pm 1.1$ \\
Pectoral-fin spine length & 17.3 & $17.3-23.4$ & $19.3 \pm 2.2$ \\
Posterior cleithral process length & 14.3 & $9.4-14.3$ & $11.9 \pm 1.8$ \\
Predorsal length & 38.2 & $38.0-39.5$ & $38.6 \pm 0.7$ \\
Prepelvic length & 52.3 & $48.2-56.7$ & $51.8 \pm 3.0$ \\
Preanal length & 51.6 & $51.6-74.5$ & $68.8 \pm 8.6$ \\
Caudal peduncle depth & 10.6 & $10.6-12.9$ & $11.5 \pm 0.9$ \\
Caudal peduncle length & 12.7 & $12.7-18.6$ & $15.3 \pm 2.1$ \\
Body width & 29.2 & $27.3-31.1$ & $29.2 \pm 1.7$ \\
Body depth at dorsal fin & 17.8 & $17.8-26.7$ & $20.1 \pm 3.3$ \\
Dorsal-fin base length & 14.8 & $9.1-15.4$ & $12.6 \pm 2.5$ \\
Adipose-fin base length & 19.2 & $15.0-19.8$ & $18.0 \pm 1.8$ \\
Anal-fin base length & 12.5 & $9.9-13.1$ & $11.4 \pm 1.3$ \\
& Proportion of head length & \\
Head depth & 42.5 & $40.8-47.5$ & $44.3 \pm 2.6$ \\
Interorbital width & 44.1 & $44.1-51.2$ & $46.4 \pm 2.7$ \\
Orbital diameter & 14.3 & $8.5-14.3$ & $10.6 \pm 2.0$ \\
Snout length & 38.5 & $37.5-45.8$ & $40.8 \pm 3.0$ \\
Mouth width & 72.0 & $61.5-72.0$ & $65.8 \pm 3.9$ \\
Maxillary-barbel length & 92.8 & $92.8-146.1$ & $118.3 \pm 17.4$ \\
\hline
\end{tabular}

Color in alcohol. Ground color light brown; flanks covered by several darker stripes. Dorsal and lateral head dark brown, limited posterior at vertical trough pectoral fin; light stripe between posterior nostril and eye; thin, undulated light stripe between anterior and posterior nostrils. Large, quadrangular dark brown saddle on trunk, starting soon after vertical through base of pectoral fin, finishing at vertical through posterior dorsal-fin base. Dark brown blotch V-shaped on trunk, starting soon after dorsal fin, finishing at middle adipose fin, rarely surpassing body axis ventrally. Caudal peduncle dark brown blotch Y-shaped. Dorsal-fin base dark brown blotch confluent anteriorly to dark brown arched stripe along superior third dorsal-fin; oval-shaped hyaline blotch between dark brown areas; hyaline superior margin. Rounded light spot on dorsal-fin anterior base. Pectoral fin hyaline; several dark brown spots on middle region. Pelvic fin hyaline; several spots scattered irregularly. Dark brown blotch on anterior half of adipose fin confluent downward with V-shaped blotch of trunk. Dark brown blotch on anterior region of anal-fin base; dark brown stripe on posterior third. Caudal fin hyaline; dark brown spots scattered irregularly; dark brown stripe on posterior third. Ventral region light brown, covered by dark brown spots.

Distribution. Known from the upper rio Paraguay basin, in Mato Grosso and Mato Grosso do Sul states, Brazil (Fig. 3), in one of the largest wetland regions in the world known as Pantanal. However, M. leniceae seems to be not common in the flooded area, occurring preferentially in small streams, as can be inferred from collection localities. Besides that, the species is possibly rare, as noticed by its absence in surveys of fish species for that region (Willink et al., 2000; Teresa et al., 2010; Severo-Neto, 2015).

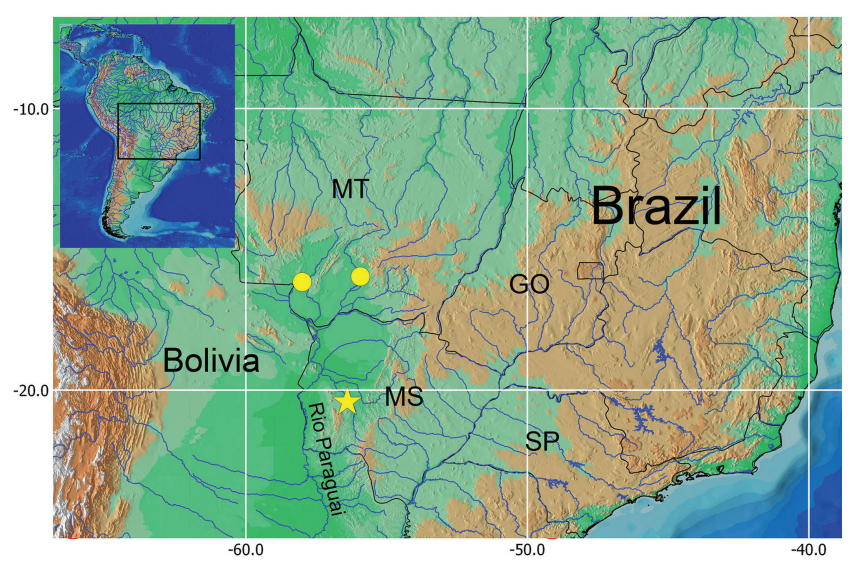

Fig. 3. Geographic distribution of Microglanis leniceae in states of Mato Grosso (MT) and Mato Grosso do Sul (MS) (yellow star $=$ type locality). Brazilian states acronyms: GO $=$ Goiás; $\mathrm{SP}=$ São Paulo.

Etymology. The specific epithet is homage to Lenice Souza Shibatta, for her dedication to the study of biogeography and evolution of Neotropical fishes. A genitive noun.

Multivariate morphometrics analysis. The first Principal Component (PC) retained the largest amount of variance, $90.52 \%$ of original data, and all loadings of characters presented positive values. The second PC retained 3.36\% and the third, $2.42 \%$, with positive and negative characters loadings (Table 2). Microglanis leniceae differs from $M$. carlae in the second PC, and from M. cottoides in the third PC (Fig. 4). The variables that distinguish M. leniceae from M. carlae were the larger preanal length, adipose-fin base length, caudal peduncle depth (highest positive values), and the smaller orbital diameter (highest negative values); $M$. leniceae differs from $M$. cottoides by the larger body width 
(highest positive value), and shorter adipose-fin base length, anal-fin base length, posterior cleithral process length, and preanal length (highest negative values).

Table 2. Loadings of characters, eigenvalue and percentages of variance on first three Principal Components axis (PC1PC3), from the analysis of combined samples of Microglanis leniceae $(\mathrm{n}=6)$, M. carlae $(\mathrm{n}=9)$ and M. cottoides $(\mathrm{n}=7)$.

\begin{tabular}{lccc}
\hline & PC1 & ShearedPC2 & ShearedPC3 \\
\hline Standard length & 0.195001 & -0.008698 & 0.090347 \\
Head length & 0.212373 & 0.049486 & 0.045401 \\
Interorbital width & 0.197606 & -0.018352 & -0.033466 \\
Orbital diameter & 0.229321 & -0.606059 & -0.129629 \\
Snout length & 0.196460 & 0.152083 & 0.052126 \\
Mouth width & 0.217175 & 0.039774 & 0.049849 \\
Maxillary barbel length & 0.161459 & -0.036518 & 0.140108 \\
Pelvic fin length & 0.195257 & -0.055775 & 0.146366 \\
Dorsal-fin spine length & 0.216646 & 0.075786 & 0.154311 \\
Pectoral-fin spine length & 0.247000 & -0.078143 & 0.166862 \\
Posterior cleithral process length & 0.305656 & -0.145145 & -0.341022 \\
Predorsal length & 0.195277 & 0.033412 & 0.086692 \\
Prepelvic length & 0.205904 & 0.019946 & 0.119410 \\
Preanal length & 0.233464 & 0.567386 & -0.192885 \\
Caudal peduncle depth & 0.204813 & 0.211335 & 0.151192 \\
Caudal peduncle length & 0.167568 & 0.123586 & 0.033589 \\
Body width & 0.208917 & 0.056911 & 0.312646 \\
Dorsal-fin base length & 0.278154 & -0.222623 & 0.092792 \\
Adipose-fin base length & 0.294856 & 0.254592 & -0.636464 \\
Anal-fin base length & 0.246763 & -0.260195 & -0.408984 \\
Eigenvalue & 0.319 & -0.012 & -0.009 \\
Percentage of total variance & 90,52 & 3,36 & 2,42 \\
\hline
\end{tabular}

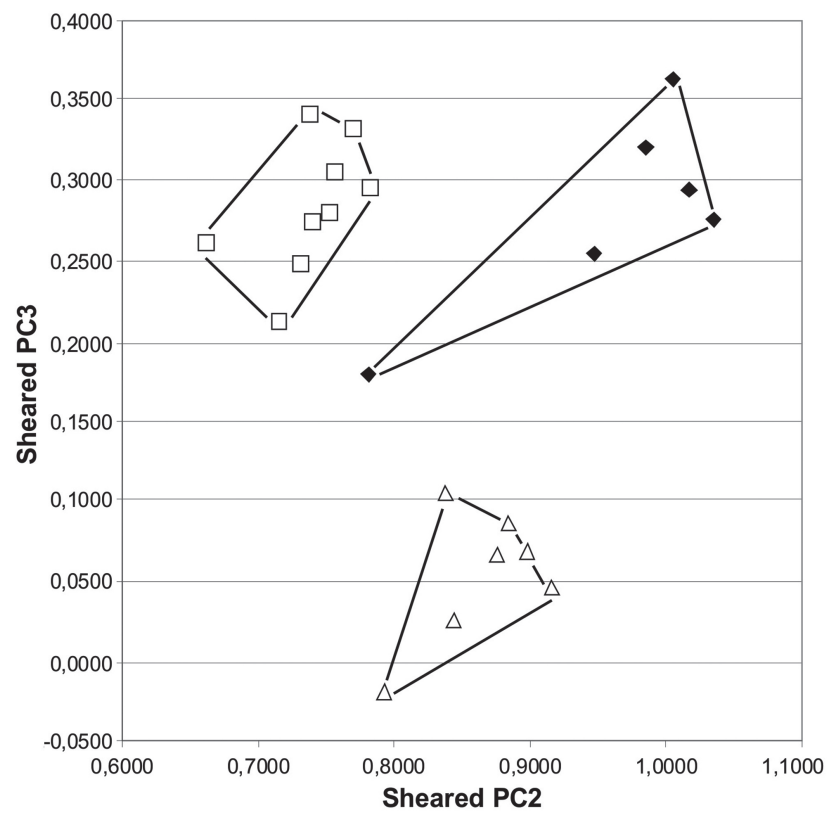

Fig. 4. Scatter diagram of Sheared Principal Components analysis of combined samples of Microglanis leniceae (diamond, $\mathrm{n}=6$ ), M. carlae (squares, $\mathrm{n}=9$ ), and $M$. cottoides (triangle, $\mathrm{n}=7$ ).
Conservation status. Few specimens of $M$. leniceae were obtained from collections, even if fish surveys in the region are made with frequency, leading to assume that the species is rare. However, the geographic distribution of $M$. leniceae at Pantanal region must be wide, as noticed from the dispersed localities of studied material in a broad geographic region with up to $115,000 \mathrm{~km}^{2}$. In light of extent of occurrence superior to $20,000 \mathrm{~km}^{2}$, without fragmentation, and lack of evidence indicating population decline or fluctuations, the current status of $M$. leniceae should be "Least Concern" or LC, according to IUCN Standards and Petitions Subcommittee (2016).

\section{Discussion}

Identification of Microglanis cottoides made by Britski et al. (2007) for the Pantanal, was based on material not catalogued, and using the original description published by Boulenger (1891). Polaz et al. (2014) mentioned the species to the National Park of Pantanal Matogrossense, based on specimens deposited in the collection of Embrapa-Pantanal. However, according to its curator Agostinho Catella (pers. comm.), the specimens are not deposited in that collection. Thus, the occurrence of $M$. cottoides in the Pantanal region cannot be confirmed, and may be a misidentification. Therefore, only $M$. leniceae is currently confirmed to occur in the Pantanal, and it is possible that this is the species anteriorly identified as $M$. cottoides. However, only the specimens examined by Britski et al. (2007) is recovered, or more effort to collect specimens of Microglanis throughout the Pantanal, allow us to test this hypothesis.

Among the diagnostic characters of M. leniceae, the caudal fin deeply forked with pointed lobes is uncommon among Microglanis, and is shared only with M. lundbergi from Amazon basin. This caudal shape easily distinguishes $M$. leniceae from $M$. cottoides, which caudal fin is emarginated with rounded lobes, the most common feature in Microglanis. However, a paratype of M. leniceae (ZUFMS-PIS 4143) presented a caudal fin with almost straight posterior margin, which should be an anomaly and not a characteristic of the species.

In Microglanis, the hooks on the anterior margin of the pectoral-fin spine can be antrorses, retrorses and sometimes bifurcated. The latter condition is usually present in adults of some species, as seen in M. poecilus Eigenmann, 1912, M. iheringi Gomes, 1946 (Mees, 1974), M. pellopterygius Mees, 1978 (Mees, 1978), M. robustus Ruiz \& Shibatta, 2010 (Ruiz \& Shibatta, 2010), M. xylographicus Ruiz \& Shibatta, 2011, M. oliveirai Ruiz \& Shibatta, 2011 (Ruiz \& Shibatta, 2011), M. lundbergi (Jarduli \& Shibatta, 2013), and M. leniceae. As noted in juvenile of M. maculatus Shibatta, 2014 (Shibatta, 2014), the hooks of the anterior margin of the pectoral fin spine are retrorse in the beginning with addition of antrorses hooks throughout the development. In $M$. leniceae the development is similar, but among antrorses and retrorses 
hooks, there is a bifurcated hook, which is formed after the development of 8 to 9 proximal retrorse hooks. To date, these bifurcated saws were observed in some species of Microglanis from Amazonia and northern South America, and it is the first record more southern.

The incomplete lateral line is shared by all species of Microglanis, usually with the canal not surpassing the vertical through end of dorsal fin. The shortest lateral line in Microglanis can be observed in M. oliveirai, in which the canal not reaches the vertical through the first branched ray of dorsal fin (Ruiz \& Shibatta, 2011). The longest lateral line in the genus occurs in $M$. iheringi, in which the canal reaches the vertical through beginning of adipose fin (Mees, 1974). However, in M. leniceae, as in $M$. maculatus, the lateral line is intermediary, surpassing the vertical through end of dorsal-fin base, but not reaching the vertical through insertion of adipose fin-base.

The color pattern in Microglanis also provides a set of characters, which if used together with other morphological variables, may be useful in the diagnosis of species. For example, the dorsal and lateral surface of head in Microglanis is dark brown with light marks on the regions between the nostrils and the eye, on the adductor muscle of mandible, and on operculum. In $M$. leniceae the color pattern of these regions of head is almost homogeneously dark brown, with only a narrow clear stripe between anterior nostril and eye. This color pattern is completely different from $M$. lundbergi, other species with deeply forked caudal fin and pointed lobes, which has a large clear spot between anterior nostril and eye. These two species also differ by the light stripe on the nape, which is almost straight in M. leniceae and two juxtaposed oval spots on $M$. lundbergi.

Comparative material. Microglanis carlae: Paraguay. MHNHP 3667, $34.1 \mathrm{~mm}$ SL, holotype of Microganis carlae Alcaraz, Graça \& Shibatta, 2008, río Salado, río Paraguay basin, 26³9'S 5805'W; MZUSP 98255, 5, 23.4-29.1 mm SL, paratypes of Microganis carlae Alcaraz, Graça \& Shibatta, 2008. Microglanis cibelae: Brazil. Rio Grande do Sul. MCP 19822, paratypes, 3, 34.9-48.7 $\mathrm{mm} \mathrm{SL}$, arroio do Ouro, tributary of rio Maquiné, 29³4'00"S 50¹6'00”W; MCP 21190 , 9, 24.6-42.4 mm SL, Osório, rio Tramandaí basin, 2957'57’S $50^{\circ} 13$ '45"W. Microglanis cottoides: Brazil. Rio Grande do Sul. MCN 3977, 1, 41.57 mm SL, rio Jacuí, Laguna dos Patos basin. MCP 22733, 1, $40.54 \mathrm{~mm}$ SL, Arroio do Tigre, Laguna dos Patos basin, 29²9'25"S 5328'45"W; MCP 23004, 2, 31.8-38.8 mm SL, arroio Bom Jardim, Laguna dos Patos basin, 2950'19"S 51²3'25"W; MCP 23079, 2, 22.61-25.59 mm SL, rio São Sepe, Laguna dos Patos basin, 30¹1'8”'S 5333'35'W; MCP 33560, 1, $54,54 \mathrm{~mm}$ SL, rio Taquari, Laguna dos Patos basin, 29¹0'10"S 5153'06"W; Microglanis eurystoma: Brazil. Santa Catarina. MCP 13405, holotype, $77.6 \mathrm{~mm}$ SL, rio Uruguai, 27¹8'00”S $52^{\circ} 20^{\prime} 00^{\prime} W$. Brazil. Rio Grande do Sul; MCP 12698, 10 paratypes, 26.3-41.1 mm SL, arroio do Passo Alto, rio Uruguai basin, 28¹1'00"S 55¹6'00"W. Microglanis garavelloi: Brazil. Paraná, MZUSP 88006, holotype, 31.7 mm SL, ribeirão Taquari, upper rio Paraná basin; MZUSP 1732, paratypes, 2, 23.7-30.8 mm SL, ribeirão Taquari, 23ำ'24"S 5056'50"W; MCP 1678, 4 paratypes (3c\&s), 24.6-27.9 mm SL, ribeirão Taquari. Microglanis iheringi: Venezuela. Aragua. USNM 121985, 1 paratype, $31.3 \mathrm{~mm}$ SL, Río Turmero, Portuguesa. CAS 64403, 3, 27.4-41.0 mm SL, Río Orinoco. Microglanis leptostriatus: Brazil. Minas Gerais. MZUSP 47456, 2 paratypes, 28.4-28.7 mm SL, rio Verde, rio São Francisco basin; MZUEL 3733, 6 paratypes, 19.3-27.4 mm SL, rio Cruz, rio São Francisco basin. Microglanis maculatus: Brazil. Goiás. INPA 41133, holotype, $36.5 \mathrm{~mm}$ SL, município de Barro Alto, upper rio Tocantins basin, ribeirão Pouso Alegre, tributary of rio dos Patos, $15^{\circ} 01 ' 26^{\prime \prime} \mathrm{S}$ 4849'51"W; INPA 24044, paratypes, 2, 21.4-25.8 mm SL, município de Barro Alto, Igarapé Veredas, rio dos Patos basin; MZUEL 5925, paratype, 1, $20.5 \mathrm{~mm}$ SL, same data as holotype. Microglanis malabarbai: Brazil. Rio Grande do Sul. MCP 37252 , 1, $47.7 \mathrm{~mm}$ SL, arroio Alexandrino, rio Ijuí basin, 28¹0'25'S 544'05"W; MCP 37187, 1, $50.1 \mathrm{~mm} \mathrm{SL}$, arroio das Pedras, rio Ijuí basin, 28¹2'07'S 5404'30”W. Microglanis nigripinnis: Brazil. Rio de Janeiro. MZUSP 80223, 1, 47.2 mm SL, tributary of rio São João, Eastern basin; MZUSP 80229, 2, 38.3-43.5 mm SL, tributary of rio São João. Microglanis parahybae: Brazil. Rio de Janeiro. MNRJ 15989, 5, 30.3-34.2 mm SL, rio Dois Rios, rio Paraíba do Sul basin; MNRJ 16047, 5, 28.6-38.9 mm SL, rio Muriaé, rio Paraíba do Sul basin. Microglanis pataxo: Brazil. Bahia. MZUSP 54516, 10, 24.9-31.4 mm SL, rio Mucuri, East coast basin. Microglanis pellopterygius: Ecuador. Napo. ANSP 130437, holotype, $68.1 \mathrm{~mm}$ SL, Río Aguarico, 0006’N $76^{\circ} 51^{\prime} \mathrm{W}$; MEPN 88.4-12, 2, 22.4-23.1 mm SL, tributary of the Río Aguarico. Microglanis poecilus: Guiana. Kurupukari. ROM $60738,1,22.5 \mathrm{~mm}$ SL, unknown stream of Essequibo River, 446'20'S 5845'W; ROM 62390, 1, 17.1 mm SL, Shimiri Stream, Yawiri, Essequibo River basin, 442'13"S 58 $42^{\prime} 43^{\prime \prime W}$; ROM 62391, 1, 17.1 mm SL, Essequibo River, 448'22"S 5846'14"W. Brazil. Amazonas. INPA 28575, 3, 18.6-20.6 mm SL, rio Aripuanã, rio Madeira basin. Brazil. Roraima. INPA 28576, 3, 19.8-20.4 mm SL, igarapé Ano Bom, rio Branco basin; INPA 8052, 3, 24.8-26.2 mm SL, igarapé Maracá, rio Branco basin, Pará. INPA 6828, 3, 19.2-25.8 mm SL, rio Jamanxin, rio Tapajós basin, 5'27'11"S 5552'40"W. Microglanis robustus: Brazil. Pará. INPA 8053, holotype, $20.3 \mathrm{~mm}$ SL, lower rio Tocantins, rio Tocantins-Araguaia basin; INPA 32885,11 paratypes (2 c\&s), 18.4-23.3 mm SL, same data as holotype; INPA 7943, 2 paratypes, 20.0-22.2 mm SL; INPA 7957, 3 paratypes, 19.2-21.7 $\mathrm{mm}$ SL, Jatobal, lower rio Tocantins. Microglanis secundus: Suriname. Brokopondo. MHNG 2621.038, 6, 18.9-27.1 mm SL, rio Mindrineti. Brazil. Pará. INPA 5730, 7, 18.5-31.1 mm SL, rio Trombetas, rio Amazonas basin; INPA 7950, 3 (2 c\&s), 24.4$28.1 \mathrm{~mm}$ SL rio Trombetas, rio Amazonas basin. Microglanis variegatus: Ecuador. Vinces. USNM 083653, 1 paratype, 29.1 $\mathrm{mm}$ SL, pools in forests near Vinces. Los rios. MHNG 298.033, 2, 25.2-27.7 mm SL, Río Palenque; MHNG 1232.11, 2, 23.6-26.2 $\mathrm{mm}$ SL, Hazienda Clementina. 


\section{Acknowledgements}

The author wish to thank all curators for loaning of examined material, especially to Lucia Rapp Py-Daniel (INPA), Carla S. Pavanelli (Nupelia), Francisco Severo Neto and Fernando Carvalho (UFMS), for loaning specimens of new species. To Carla N. M. Polaz, Emiko K. Resende and Agostinho Catella (Embrapa-Pantanal) by clarifications on material cited as belonging to Embrapa. To CNPq for providing research grant to OAS (Proc. $n^{\circ}$ 304868/2015-9).

\section{References}

Alcaraz, H. S. V., W. J. Graça, \& O. A. Shibatta. 2008. Microglanis carlae, a new species of bumblebee catfish (Siluriformes: Pseudopimelodidae) from the río Paraguay basin in Paraguay. Neotropical Ichthyology, 6: 425-432.

Boulenger, G. A. 1891. An account of the siluroid fishes obtained by Dr. H. von Ihering and Herr Sebastian Wolff in the Province Rio Grande do Sul, Brazil. Proceedings of the Zoological Society of London, 1891: 231-235.

Britski, H. A., K. Z. S. Silimon, B. S. Lopes. 2007. Peixes do Pantanal: Manual de identificação. Brasília, Embrapa Informação Tecnológica, 227p.

Gomes, A. L. 1946. A review of Microglanis, a genus of South American catfishes, with notes of related genera. Ann Arbor, University of Michigan Press, 19p. (Occasional Papers of the Museum of Zoology, no. 494).

International Union for Conservation of Nature (IUCN). 2012. IUCN Red list categories and criteria 3.1. Gland; Cambridge, International Union for Conservation of Nature and Natural Resources, 32p.

International Union for Conservation of Nature (IUCN). Standards and Petitions Subcommittee. 2016. Guidelines for using the IUCN Red List Categories and Criteria. Version 12. Prepared by the Standards and Petitions Subcommittee. Available from: http://cmsdocs.s3.amazonaws.com/RedListGuidelines.pdf. (Feb 2016).

Jarduli, L. R. \& O. A. Shibatta. 2013. Description of a new species of Microglanis (Siluriformes: Pseudopimelodidae) from the Amazon basin, Amazonas State, Brazil. Neotropical Ichthyology, 11: 507-512.

Macleod, N. 1990. Shear. Unique version. Ann Arbor: The University of Michigan Museum of Zoology. Fortran. MSDOS.
Mees, G. F. 1974. The Auchenipteridae and Pimelodidae of Suriname (Pisces, Nematognathi). Zoologische Verhandelingen, 132: $1-246$.

Mees, G. F. 1978. Two new species of Pimelodidae from NorthWestern South America (Pisces, Nematognathi). Zoologische Mededelingen, 53: 253-261.

Polaz, C. N. M., B. F. Melo, R. Britske, E. K. Resende, F. A. Machado, J. A. F. Lima \& M. Petrere Júnior. 2014. Fishes from the Parque Nacional do Pantanal Matogrossense, upper Paraguai river basin, Brazil. Check List, 10: 122-130.

Ruiz, W. B. G. \& O. A. Shibatta. 2010. A new species of Microglanis (Siluriformes, Pseudopimelodidae) from lower rio Tocantins basin, Pará, Brazil, with description of superficial neuromasts and pores of lateral line system. Zootaxa, 2632: 53-66.

Ruiz, W. B. G. \& O. A. Shibatta. 2011. Two new species of Microglanis (Siluriformes: Pseudopimelodidae) from the upper-middle rio Araguaia basin, Central Brazil. Neotropical Ichthyology, 9: 697-707.

Severo Neto, F., L. F. C. Tencatt, R. Costa-Pereira \& L. E. R. Tavares. 2015. Fishes from baía da Medalha, southern Pantanal, Brazil: a 20 years review. Biota Neotropica, 15: e20140116.

Shibatta, O. A. 2014. A new species of Microglanis (Siluriformes, Pseudopimelodidae) from the upper rio Tocantins basin, Goiás state, Central Brazil. Neotropical Ichthyology, 12: 81-87.

Teresa, F. B., R. M. Romero \& F. Langeani. 2010. Pisces, Aquidauna and Miranda drainages, upper Paraguay River basin, Mato Grosso do Sul, Brazil. Check List, 6: 596-601.

Willink, P. W., O. Froehlich, A. Machado-Allison, N. Menezes, O. Oyakawa, A. Catella, B. Chernoff, F. C. T. Lima, M. ToledoPiza, H. Ortega, A. M. Zanata \& R. Barriga. 2000. Fishes of the rios Negro, Negrinho, Taboco, Aquidauana, Taquari and Miranda, Pantanal, Brasil: diversity, distribution, critical habitats and value. Pp. 63-81. In: Willink, P. W., B. Chernoff, L. E. Alonso, J. R. Montambault \& R. Lourival (Eds.). A biological assessment of the aquatic ecosystem of the Pantanal, Mato Grosso do Sul Brasil. Washington, D. C., Conservation International. (Rap Bulletin of Biological Assessment, no. 18).

Submitted March 17, 2016 Accepted August 02, 2016 by Francisco Langeani 